\title{
ARTICLE
}

\section{We Want to be More Involved: Student Perceptions of Students as Partners Across the Degree Program Curriculum}

\author{
Kelly E. Matthews ${ }^{a^{*}}$, Lauren J. Groenendijk ${ }^{b}$, Prasad Chunduri ${ }^{c}$ \\ ${ }^{a}$ Institute for Teaching \& Learning Innovation, The University of Queensland \\ ${ }^{\mathrm{b}}$ School of Biomedical Sciences, and Institute for Teaching \& Learning Innovation, The \\ University of Queensland \\ ${ }^{\mathrm{c}}$ School of Biomedical Sciences, The University of Queensland
}

Contact: k.matthews1@uq.edu.au

\section{ABSTRACT}

Engaging students-as-partners is gaining momentum in the higher education sector. This study explores undergraduate students' perceptions of how involved they were in partnership activities across their degree programs, and whether this matched their desired level of involvement in such practices. Analysis of a quantitative study of 268 students showed statistically significant differences between perceived levels of importance and involvement for all the partnership practices $(n=18)$ investigated in our survey. These results highlight that the students in this study want to be more substantially involved in partnership practices across their degree program. We argue against the consumerist rhetoric about the role of students as passive learners and advocate for greater inclusion of partnership activities that foster active student participation in shaping the university curricula. We discuss implications for Students as Partners in relation to the progressive development of university curricula and assessment practices along with future research directions.

\section{KEYWORDS}

students as partners, student perspectives, higher education

Students as Partners ( $\mathrm{SaP}$ ) is a "hot topic" in the field of higher education (Healey, Flint, \& Harrington, 2016). Emerging research focused on those engaged in SaP initiatives is identifying a range of beneficial outcomes experienced by those involved (Cook-Sather, Bovill, \& Felten, 2014; Healey, Flint, \& Harrington, 2014). As the popularity of SaP increases and universities seek to extend the reach of partnership to more students and staff, it is important to understand the views of those not engaged in SaP initiatives and investigate SaP activities across curricula. In this study, we explore 268 students' perspectives of the importance of being involved in SaP activities and their opportunities to engage in such activities across their degree programs. The study offers an evidential baseline of student 
involvement in SaP, along with a measure of the gap between students' desires to be engaged in SaP practices and the extent to which the curriculum creates such opportunities for them. Understanding these data concerning students' desire to be engaged in SaP contributes to the development of the field by illuminating views of students who are not typically represented in published SaP research and by offering new insights into how students not typically involved in SaP practices wish to be engaged in them.

\section{LITERATURE REVIEW}

SaP extends the concept of student engagement from a focus on students toward a notion of shared engagement predicated on students and staff collaborating together on shared educational goals (Matthews, 2016). This shared engagement is evident in the Healey et al. (2014) definition of partnership: "a relationship in which all involvedstudents, academics, professional services staff, senior managers, students' unions, and so on-are actively engaged in and stand to gain from the process of learning and working together" (p. 12). Going beyond listening to students' feedback on teaching activities, CookSather et al. (2014) defined partnership as "a collaborative, reciprocal process through which all participants have the opportunity to contribute equally, although not necessarily in the same ways, to curricular or pedagogical conceptualization, decision-making, implementation, investigation, or analysis" (pp. 6-7). This definition emphasises student and staff collaboration in activities that traditionally have involved only staff by signaling that students can play important roles in designing learning activities, curriculum reform efforts, teaching, and researching the effectiveness of educational interventions. SaP interactions are based on the partnership principles of respect, reciprocity, and shared responsibility in teaching and learning (Cook-Sather et al, 2014).

SaP encompasses a broad range of activities. Healey et al. (2014) proposed a framework comprising four overlapping categories where students and staff engage together as partners in:

1) Learning, teaching, and assessment

2) Subject-based research and inquiry

3) Curriculum design and pedagogic consultancy

4) Scholarship of teaching and learning

The framework highlights the range of possibilities for engaging students and staff as partners and signals the plethora of practices that can be classified as SaP, as Healey, Bovill, and Jenkins (2015) summarise:

Students may take on the role of teachers through peer-learning and assessment or through taking on responsibility for co-teaching with staff and other students; they may act as scholars through being involved in subject-based research and inquiry; and they may engage as change agents through undertaking Scholarship of Teaching and Learning (SoTL) projects, co-designing the curriculum and acting as pedagogic mentors and consultants to staff. (p. 142)

$\mathrm{SaP}$ is a recent term that encompasses existing practices while making space for possibilities not yet imagined. Early SaP research has highlighted a range of beneficial outcomes for both students and staff. For students, outcomes include increased engagement and motivation for learning, development of skills and broader outcomes linked to employability, deeper understanding of their own learning (meta-cognitive 
learning) linked to life-long learning, and a greater sense of belonging to the university (Cook-Sather et al, 2014; Healey et al., 2014). For staff, the outcomes include more enjoyment and increased motivation for teaching, deeper understanding of students' experiences, and development of enhanced teaching materials (Cook-Sather et al, 2014; Healey et al., 2014; Woolmer et al., 2016). While engaging students and staff in partnership has real challenges and hurdles, research is indicating these practices can be transformative and beneficial for both students and staff.

As a new field of inquiry, it is unsurprising that SaP research tends to be small scale, with a reliance on qualitative case study methods that inquire into the experiences of students and staff explicitly involved in partnership activities (for example see, Butcher \& Maunder, 2013; Woolmer et al., 2016, and case studies used in Cook-Sather et al, 2014; Healey et al, 2014). In a recent literature review of 65 published works explicitly investigating SaP through empirical research, Mercer-Mapstone et al. (2017) found the studies were predominantly small-scale case studies drawing on the qualitative experiences of those involved in SaP practices. Such studies are highly contextualised to the sociocultural context of their institutions and tend to explore a micro-level focus on specific learning activities, classroom-level practices, or small-scale extra-curricular projects. They offer rich descriptions and insights into the lived experience of engaging as a partner in teaching and learning. As Mercer-Mapstone et al. (2017) argue, this focus, while important, is limited to the experiences, insights, and understandings of those involved to the exclusion of those not involved. If we believe that opportunities to shape one's education should be made available to all students, as suggested by Healey et al.'s (2014) model of "partnered learning communities" and Matthews, Cook-Sather, and Healey's (in press) notion of "egalitarian learning communities," then understanding the views of students not involved in partnership seems an important piece of the overall SaP research landscape. At present, however, little is known about SaP practices at the macro-level of degree programs and the views of students not explicitly involved in such practices.

Research capturing the SaP experiences and beliefs of larger cohorts of students and staff would advance the field of SaP, providing baseline evidence of the extent to which SaP activities are included in the curriculum and guiding further curriculum development to scaffold such activities across degree programs. This study explores the macro-level of degree programs by focusing on the broader student cohort using a large-scale quantitative research design.

\section{PURPOSE AND CONTRIBUTION}

Our aim is to contribute to the growing SaP body of research by asking students questions about their perceptions of SaP across their degree program. The rationale for exploring the student perspective on SaP draws on ideas of student voice that give value and privilege to what students think about their education by virtue of being essential partners in learning and teaching (Cook-Sather, 2002; 2006). We acknowledge that students have expertise in the student experience and can offer valuable perspectives that should shape and reframe curricular practices, particularly how SaP practices are scaffolded across degree programs. The study is guided by the following research questions:

\section{How important is it to undergraduate students to be involved in SaP practices?}




\section{To what extent are opportunities for student involvement in SaP practices included in their degree program curriculum?}

Exploring these questions offers insight into the gap between students' perceptions of the importance of SaP practices and their inclusion in the degree program curriculum. This is an exploratory study that establishes an evidential baseline about SaP practices in a degree program.

\section{METHODS}

This study employed a quantitative design to capture data from a large group of students. The study received approval from our Institutional Human Research Ethics Committee (approval \#2016000441).

\section{Context}

This study was conducted at a research-intensive Australian higher education institution ranked within the top 100 universities worldwide (see, for example, Times Higher Education and QS rankings). The institution has a traditional model for teaching with strong disciplinary faculties focused on research excellence. Recent efforts to raise the profile of teaching and the student experience include a new five-year "student strategy" with SaP as a central pillar for institutional transformation of teaching and learning. The study was conducted in the Faculty of Science, which offers a three-year Bachelor of Science (BSc) degree with an optional fourth Honours-research year and a four-year Bachelor of Biomedical Science (B.Biomed.Sc) degree. Both programs offer undergraduate research opportunities as they are recognized to as integral to learning science within a traditional, discipline-oriented curriculum.

\section{Data collection instrument}

The Science Students Skills Inventory (SSSI) instrument developed by Matthews and Hodgson (2012) was adapted for this study. The SSSI is an established survey tool that collects student perception data about degree-program learning outcomes at the wholeprogram level using several indicators and has been used in many studies (see Dvorakova \& Matthews, 2016; Matthews \& Mercer-Mapstone, 2016; Varsavsky, Matthews, \& Hodgson, 2014). The SSSI was adapted to focus on partnership activities across two indicators: importance and inclusion.

The survey focused on tangible partnership practices. The Healey et al. (2014) fourcategory model was used to identify relevant partnership activities, along with our insider knowledge of the undergraduate curriculum: Groenendijk is a BSc student, Chunduri is a lecturer, and Matthews is a science curriculum consultant. Groenendijk drafted a list of potential activities and we revised them together. In this process, we acknowledged that certain practices (e.g., end-of-semester class evaluation surveys; being a class representative for a unit) were not partnership practices, but these were familiar ways for students to offer feedback. Thus, Groenendijk in particular felt it important to include such items, as students would expect to see them. We agreed they could offer insightful comparisons across a spectrum of gathering student feedback, on one end, to partnership practices, on the other end. We then created the survey instrument and piloted it with four undergraduate students to gauge how they interpreted the questions and activities. We revised accordingly with the final survey exploring 18 partnership practices. 
The survey consisted of questions on a 4-point alpha-numeric scale as per Table 1. Participants were asked to rate the perceived importance of each activity from "not at all" (1) to "a lot" (4). A "not sure what this means" option was included to prevent participants from being forced to guess on practices they did not understand. Participants were then asked to rate on the same 4-point scale how involved they have been throughout their degree program in these 18 activities. We also did not imagine that all students would indicate high levels of agreement for importance or inclusion; our aim was to explore the gap between them for the 18 practices. Demographic information was collected, which included year level, gender, and post-graduation plans.

Table 1: Example of survey question and alpha-numeric scale used to collect student responses

\begin{tabular}{|l|l|l|l|l|l|}
\hline \multicolumn{4}{|l|}{ How IMPORTANT do you think it is to have the following included in your degree? } \\
\hline $\begin{array}{l}\text { SaP } \\
\text { Practice } \\
\text { listed }\end{array}$ & $\begin{array}{l}\text { Not at all } \\
(1)\end{array}$ & A little (2) & $\begin{array}{l}\text { A moderate } \\
\text { amount (3) }\end{array}$ & $\begin{array}{l}\text { A lot } \\
(4)\end{array}$ & Not sure what this means \\
\hline
\end{tabular}

\section{Participants}

The survey instrument was administered online to all students enrolled either in a four-year B.Biomed.Sc program with Honours or a three-year BSc degree with an optional Honours year. In total, 1,208 students were emailed an invitation to complete the survey, which was open for 1 week. A total of 289 students opened the survey and answered at least one question giving a total response rate of $24 \%$. Taking into account the population size, the response rate is adequate for reducing sampling error and maximising confidence level (Nulty, 2008). For the purposes of analysis, surveys with $25 \%$ or fewer questions completed were removed, leaving 268 surveys for inclusion in the data analysis. Of the respondents included in this study, $48 \%(n=129)$ were enrolled in third or fourth year and $52 \%(n=139)$ were enrolled in first or second year. The graduation plans identified by participating students favoured attending medical school $(n=58 \%)$, other postgraduate degree $(24 \%)$, another undergraduate degree $(2 \%)$, work ( $9 \%)$, no set plans $(6 \%)$ and other (1\%). Females were $67 \%$ of respondents, while the cohort is typically made up of $50 \%$ female students.

\section{Analysis}

The GraphPad Prism 7 statistical software package was used for all statistical calculations, including descriptive statistics and paired t-tests. For the purpose of analysis, "I don't understand what this means" answers were removed. Each partnership category was treated separately so that even if a participant did not understand some categories, the rest of their answers were kept for data analysis. Due to the alpha-numeric item nature of the survey, the data was treated as continuous as per common practice (Weng, 2004).

Descriptive statistics, including mean and standard deviation, were calculated for each partnership activity for both perceived importance and involvement. Data graphs were created using the mean. Percentage agreement was also calculated for data tables, with " 3 " and " 4 " classified as "agree" as is standard and accepted survey practice for a balanced scale. 
Paired t-tests were performed to a confidence level of $95 \%(p>0.05)$ to assess differences between perceived importance and involvement in each partnership activity. Gap analysis tables were created to assess which categories had the greatest differences. Analysis of variance (ANOVA) was performed to analyse the difference between group means to test the hypothesis that demographics (i.e., gender, year level in degree program, post-graduation plans) may influence how students considered partnership activities to be included in their degree.

\section{LIMITATIONS}

This study has several limitations worth acknowledging so readers can take care when interpreting and generalising its findings. First, the study is situated in one institution and one disciplinary context. As an exploratory study using a method unique to the field of SaP research, readers should take care to generalise to other disciplines or institutional contexts. Second, the study was focused on SaP practices, not the principles and values that underpin SaP. Thus, the study offers no insight into how SaP practices were experienced in relation to any values. Third, the $18 \mathrm{SaP}$ practices investigated were not exhaustive, and, as such, the data collection instrument does not represent SaP broadly. Fourth, a sample of students elected to participate in our volunteer study. While many did not elect to participate, we cannot speculate as to their reasons why. This study is reflective of the students who did engage and care should be taken to generalise to the broader student population. Finally, as a quantitative study exploring perceptions of importance and inclusion using fixed prompts, the study offers no sense of quality of the experiences or outcomes of being involved in the $18 \mathrm{SaP}$ practices.

\section{RESULTS}

The results present students' perceptions of the importance of being involved in 18 SaP practices, with importance being an indicator of what matters to students, which is distinct from a priority or prioritising what students might like to see implemented in practice. The results also present students' perceptions of the extent to which opportunities for student involvement were included in their degree program; included indicated what students identified as being available to them across their curricula. The results are displayed based on the Healey et al. (2014) categories, which presents clusters of data around similar types of partnership activities. The categories of "subject-based research and inquiry" and "SoTL" have been combined because these two practices that involve coinquiry and co-researchers explored in the survey could fit into either category.

The results from the analysis of variance or ANOVA exploring differences between demographic variables (i.e., gender, year level in degree program, post-graduation plans) found very limited influence on perceptions of SaP being included in the curriculum.

\section{Results for "learning, teaching, and assessment" practices}

The results for the seven partnership activities in this category are presented in Table 2 and Figure 1, and showed statistically significant differences between students' perceptions of importance and involvement, with importance being higher across all activities. 
Table 2: Levels of perceived importance and involvement (means, percentage agree) of students across seven practices in the "teaching, learning, and assessment" category

\begin{tabular}{|c|c|c|c|c|c|}
\hline SaP Practice & $\begin{array}{l}\text { \# of } \\
\text { Response } \\
\mathrm{s}\end{array}$ & $\begin{array}{l}\text { Importance } \\
\% \text { agree } \\
M(S D)\end{array}$ & $\begin{array}{l}\text { Involvement } \\
\% \text { agree } \\
M(\mathrm{SD})\end{array}$ & $\begin{array}{l}\text { Statistical } \\
\text { Significance } \\
\text { Level (Means) }\end{array}$ & $\begin{array}{l}\text { Gap } \\
\% \text { agree } \\
\text { M }\end{array}$ \\
\hline $\begin{array}{l}\text { Being a tutor or lab } \\
\text { demonstrator for courses }\end{array}$ & 260 & $\begin{array}{l}72 \% \\
2.92( \pm 0.93)\end{array}$ & $\begin{array}{l}13 \% \\
1.35( \pm 0.81)\end{array}$ & $p<0.0001$ & $\begin{array}{l}59 \% \\
1.57\end{array}$ \\
\hline $\begin{array}{l}\text { Negotiating assessment } \\
\text { criteria and grade } \\
\text { weightings with instructors }\end{array}$ & 261 & $\begin{array}{l}64 \% \\
2.79( \pm 0.96)\end{array}$ & $\begin{array}{l}8 \% \\
1.35( \pm 0.66)\end{array}$ & $p<0.0001$ & $\begin{array}{l}56 \% \\
1.44\end{array}$ \\
\hline $\begin{array}{l}\text { Being a peer assisted study } \\
\text { session (PASS) leader }\end{array}$ & 257 & $\begin{array}{l}65 \% \\
2.81( \pm 0.95)\end{array}$ & $\begin{array}{l}16 \% \\
1.43( \pm 0.92)\end{array}$ & $p<0.0001$ & $\begin{array}{l}49 \% \\
1.38\end{array}$ \\
\hline $\begin{array}{l}\text { Negotiating assessment } \\
\text { deadlines with instructors }\end{array}$ & 264 & $\begin{array}{l}55 \% \\
2.60( \pm 1.04)\end{array}$ & $\begin{array}{l}11 \% \\
1.39( \pm 0.76)\end{array}$ & $p<0.0001$ & $\begin{array}{l}44 \% \\
1.21\end{array}$ \\
\hline $\begin{array}{l}\text { Selecting from a choice of } \\
\text { assessment topics in class }\end{array}$ & 254 & $\begin{array}{l}80 \% \\
3.19( \pm 0.85)\end{array}$ & $\begin{array}{l}42 \% \\
2.29( \pm 0.99)\end{array}$ & $p<0.0001$ & $\begin{array}{l}38 \% \\
0.90\end{array}$ \\
\hline $\begin{array}{l}\text { Self-assess your own work } \\
\text { as part of an assignment }\end{array}$ & 263 & $\begin{array}{l}58 \% \\
2.73( \pm 1.00)\end{array}$ & $\begin{array}{l}36 \% \\
2.23( \pm 1.02)\end{array}$ & $p<0.0001$ & $\begin{array}{l}22 \% \\
0.50\end{array}$ \\
\hline $\begin{array}{l}\text { Peer review of assessment } \\
\text { for other students }\end{array}$ & 264 & $\begin{array}{l}62 \% \\
2.76( \pm 0.94)\end{array}$ & $\begin{array}{l}43 \% \\
2.35( \pm 0.88)\end{array}$ & $p<0.0001$ & $\begin{array}{l}19 \% \\
0.41\end{array}$ \\
\hline
\end{tabular}

Being a tutor or lab demonstrator for courses

Negotiating assessment criteria and grade weightings with instructors

Being a peer assisted study session (PASS) leader

Negotiating assessment deadlines with instructors

Selecting from a choice of assessment topics in class

Self-assess your own work as part of an assignment

Peer review of assessment for other students

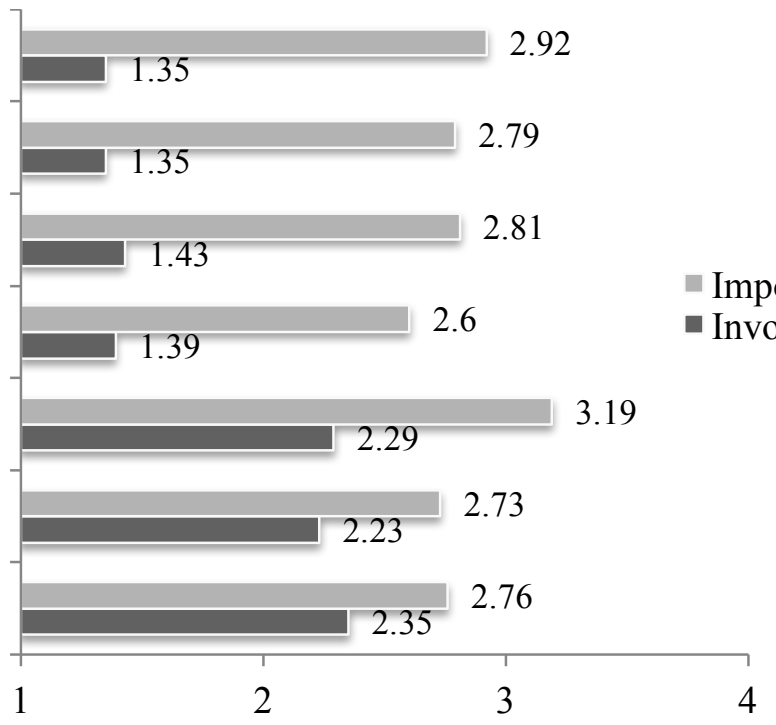

Figure 1: Graphical comparison of perceived importance and involvement (means) of students across seven practices in the "teaching, learning, and assessment" category.

\section{Results for "curriculum design and pedagogic consultancy" practices}

The results for the nine partnership activities in this category are presented in Table 3 and Figure 2 . Similar to the previous category, data showed statistically significant differences between students' perceptions of importance and involvement, with importance 
being higher across all activities. However, "end of semester class evaluation surveys" was found to be less statistically significant in comparison to all other partnership activities.

Table 3: Levels of perceived importance and involvement (means, percentage agree) of students across nine practices in the "curriculum design and pedagogic consultancy" category

\begin{tabular}{|c|c|c|c|c|c|}
\hline SaP Practice & $\begin{array}{l}\text { \# of } \\
\text { responses }\end{array}$ & $\begin{array}{l}\text { Importance } \\
\% \text { agree } \\
M(\mathrm{SD})\end{array}$ & $\begin{array}{l}\text { Involvement } \\
\% \text { agree } \\
M(\mathrm{SD})\end{array}$ & $\begin{array}{l}\text { Statistical } \\
\text { Significance } \\
\text { Level (Means) }\end{array}$ & $\begin{array}{l}\text { Gap } \\
\% \text { agree } \\
\text { M }\end{array}$ \\
\hline $\begin{array}{l}\text { Conversations with } \\
\text { instructors to improve } \\
\text { teaching practices }\end{array}$ & 254 & $\begin{array}{l}87 \% \\
3.39( \pm 0.76)\end{array}$ & $\begin{array}{l}20 \% \\
1.77( \pm 0.88)\end{array}$ & $p<0.0001$ & $\begin{array}{l}67 \% \\
1.62\end{array}$ \\
\hline $\begin{array}{l}\text { Co-designed course } \\
\text { materials with instructors }\end{array}$ & 253 & $\begin{array}{l}65 \% \\
2.83( \pm 0.96)\end{array}$ & $\begin{array}{l}12 \% \\
1.35( \pm 0.76)\end{array}$ & $p<0.0001$ & $\begin{array}{l}53 \% \\
1.48\end{array}$ \\
\hline $\begin{array}{l}\text { Co-designed assessment } \\
\text { tasks with instructors }\end{array}$ & 252 & $\begin{array}{l}64 \% \\
2.80( \pm 0.88)\end{array}$ & $\begin{array}{l}12 \% \\
1.38( \pm 0.75)\end{array}$ & $p<0.0001$ & $\begin{array}{l}53 \% \\
1.42\end{array}$ \\
\hline $\begin{array}{l}\text { Developing assessment } \\
\text { marking criteria with } \\
\text { instructors as part of a }\end{array}$ & 260 & $\begin{array}{l}57 \% \\
2.70( \pm 0.99)\end{array}$ & $\begin{array}{l}9 \% \\
1.35( \pm 0.76)\end{array}$ & $p<0.0001$ & $\begin{array}{l}48 \% \\
1.35\end{array}$ \\
\hline $\begin{array}{l}\text { Drafting assessment } \\
\text { questions for instructors } \\
\text { as part of a class }\end{array}$ & 259 & $\begin{array}{l}61 \% \\
2.76( \pm 0.99)\end{array}$ & $\begin{array}{l}17 \% \\
1.53( \pm 0.81)\end{array}$ & $p<0.0001$ & $\begin{array}{l}44 \% \\
1.23\end{array}$ \\
\hline $\begin{array}{l}\text { Student forums to discuss } \\
\text { degree program curricula, } \\
\text { teaching, or learning }\end{array}$ & 262 & $\begin{array}{l}75 \% \\
3.10( \pm 0.85)\end{array}$ & $\begin{array}{l}31 \% \\
2.00( \pm 1.03)\end{array}$ & $p<0.0001$ & $\begin{array}{l}44 \% \\
1.10\end{array}$ \\
\hline $\begin{array}{l}\text { Being a student } \\
\text { representative on a } \\
\text { university committee }\end{array}$ & 264 & $\begin{array}{l}41 \% \\
2.31( \pm 0.95)\end{array}$ & $\begin{array}{l}12 \% \\
1.41( \pm 0.81)\end{array}$ & $p<0.0001$ & $\begin{array}{l}29 \% \\
0.90\end{array}$ \\
\hline $\begin{array}{l}\text { Being a class } \\
\text { representative for a unit }\end{array}$ & 246 & $\begin{array}{l}33 \% \\
2.18( \pm 0.92)\end{array}$ & $\begin{array}{l}10 \% \\
1.34( \pm 0.70)\end{array}$ & $p<0.0001$ & $\begin{array}{l}23 \% \\
0.84\end{array}$ \\
\hline $\begin{array}{l}\text { End of semester class } \\
\text { evaluation survey }\end{array}$ & 247 & $\begin{array}{l}86 \% \\
3.40( \pm 0.77)\end{array}$ & \begin{tabular}{|l|}
$82 \%$ \\
$3.26( \pm 0.94)$
\end{tabular} & $p<0.05$ & $\begin{array}{l}4 \% \\
0.14\end{array}$ \\
\hline
\end{tabular}


Conversations with instructors to improve teaching practices

Co-designed course materials with instructors

Co-designed assessment tasks with instructors

Developing assessment marking criteria with instructors as part of a class

Drafting assessment questions for instructors as part of a class

Student forums to discuss degree program curricula, teaching or learning

Being a student representative on a university committee

Being a class representative for a unit

End of semester class evaluation survey

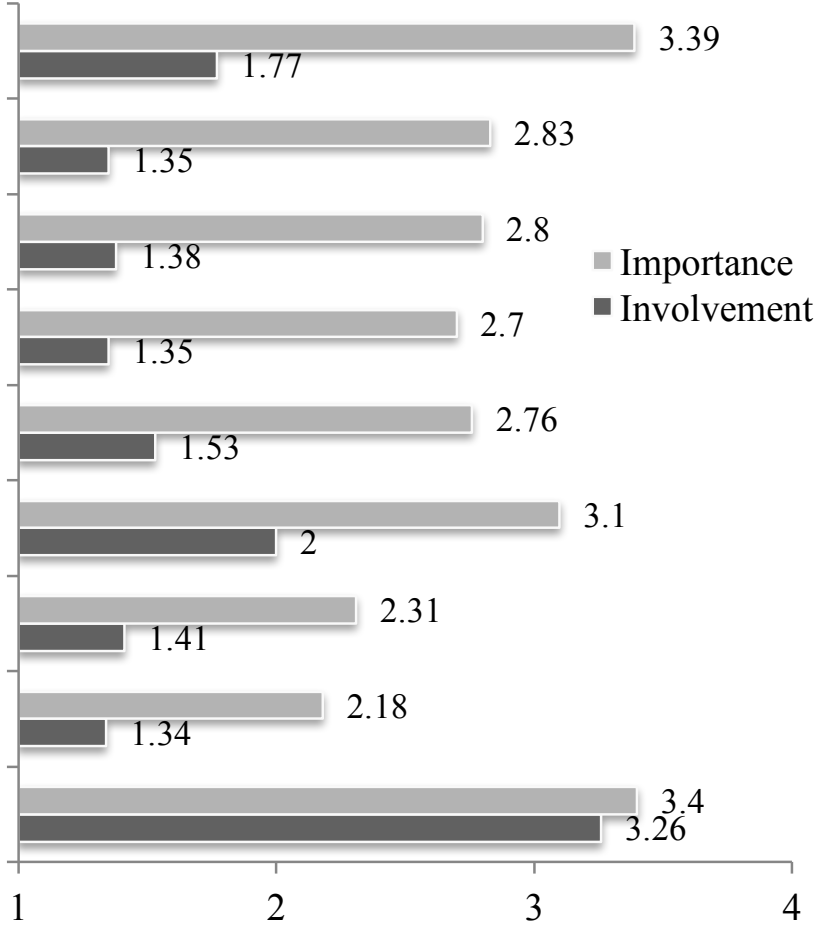

Figure 2: Graphical comparison of perceived importance and involvement (means) of students across nine practices in the "curriculum design and pedagogic consultancy" category.

\section{Results for "subject-based research and inquiry" and SoTL practice}

The results for the two partnership activities in these two categories are presented in Table 4 and Figure 3 and showed statistically significant differences between students' perceptions of importance and involvement, with importance being higher across all activities.

Table 4: Levels of perceived importance and involvement (means, percentage agree) of students across two practices in the "subject-based research and inquiry" and "SoTL"" categories

\begin{tabular}{|l|l|l|l|l|l|}
\hline SaP Practice & $\begin{array}{l}\text { \# of } \\
\text { responses }\end{array}$ & $\begin{array}{l}\text { Importance } \\
\% \text { agree } \\
M(S D)\end{array}$ & $\begin{array}{l}\text { Involvement } \\
\% \text { agree } \\
M(S D)\end{array}$ & $\begin{array}{l}\text { Statistical } \\
\text { Significance } \\
\text { Level (Means) }\end{array}$ & $\begin{array}{l}\text { Gap } \\
\% \text { agree } \\
\mathrm{M}\end{array}$ \\
\hline $\begin{array}{l}\text { Undergraduate research } \\
\text { projects collaborating with } \\
\text { instructors in their research }\end{array}$ & 257 & $\begin{array}{l}8 \% \\
3.29( \pm 0.92)\end{array}$ & $\begin{array}{l}29 \% \\
1.85( \pm 1.09)\end{array}$ & $\mathrm{p}<0.0001$ & $53 \%$ \\
\hline $\begin{array}{l}\text { Co-authoring a manuscript } \\
\text { with an instructor }\end{array}$ & 257 & $\begin{array}{l}67 \% \\
2.83( \pm 0.99)\end{array}$ & $\begin{array}{l}14 \% \\
1.41( \pm 0.81)\end{array}$ & $\mathrm{p}<0.0001$ & 1.44 \\
\hline
\end{tabular}


Undergraduate research projects collaborating with instructors in their research

Co-authoring a manuscript with an instructor

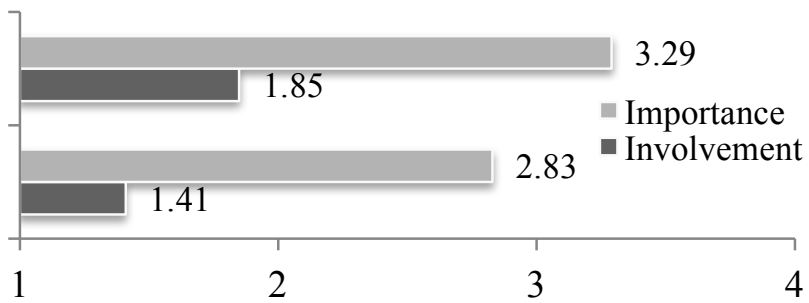

Figure 3: Graphical comparison of perceived importance and involvement (means) of students across two practices in the "subject-based research and inquiry" and "SoTL" categories.

\section{DISCUSSION}

The purpose of this study was to explore how involved undergraduate science students are in partnership activities, and whether this matched desired involvement at the degree program level. The analysis of results from the 268 students included in the study analysis showed statistically significant differences between their perceived levels of importance and involvement for all $18 \mathrm{SaP}$ activities investigated in the survey. These results show that students perceive these SaP practices are more important compared to their opportunities to be engaged in such SaP practices.

The Healey et al. (2014) framework highlights the ways that students and staff can become co-teachers or co-inquirers in subject-based or institutional SoTL research projects and co-designers or co-creators in curriculum and assessment endeavours. Our findings indicate large gaps in students' perceptions, suggesting co-teaching, co-creating, and coinquirer forms of partnership are important relative to existing opportunities for engagement in such practices. While there were high levels of agreement on the importance of SaP practices, others have shown some student resistance to engaging in SaP practices (Seale, Gibson, Haynes, \& Potter, 2015). Having baseline perception data from students allows instructors to have a better sense of where resistance might occur to specific practices so they may more explicitly state the purpose of adopting SaP approaches.

The smallest gap in the survey was students giving feedback on class (subject) teaching evaluation surveys, which are required to be administered online for all classes at the university being studied. Although this activity is better recognised as "listening to students" than engaging them as partners, students in this study valued it. Practices emphasising dialogue between students and instructors via "conversations with instructors to improve teaching practices" and "student forums to discuss curricula, teaching, or learning" had high levels of perceived importance, with substantial gaps indicating limited engagement in such conversations in the curricula. Models such as Cook-Sather's (2014; 2016) "Students as Learners and Teachers" encourage such ongoing dialogue between instructors and students through structured interactions focused on enhancing educational practices. In the biomedical sciences curriculum of the university in this study, no such models exist. These data indicate that such programs and more active forms of engagement than simply responding to a class teaching evaluation survey would be welcomed from students who are seeking dialogue about their educational experiences. However, official student representative roles on committees and in classes were perceived as less important by students in this study. While there has been a lot of focus on "student voice in governance" (Lizzio \& Wilson, 2009), students in this study were less interested in such opportunities. These findings make sense in light of some student unions also emphasising that students and staff working in partnership extends far beyond involving representative students in decision-making on institutional committees (HEA and NUS, 2011). 
The dearth of research investigating students' involvement in or perceptions of SaP activities across their degree program curriculum makes comparison to existing literature difficult. This study provides an evidential baseline for the wide scope possible for SaP and invites further quantitative research at the degree program level in other disciplines and other institutional contexts. There are several implications for SaP arising from our results, which we will discuss below under the following broad headings: (a) students as consumers or partners in learning and teaching, (b) progressive development of SaP in assessment practices, (c) SaP in curriculum development, and (d) further SaP research.

\section{Students as consumers or partners in learning and teaching}

In many ways, the emergence of SaP was a response to the changing nature of the discourse of students in higher education, particularly the rhetoric of "students as customers." A recent university graduate opinion piece, "We are not customers" (Afolabi \& Stockwell, 2012), challenged the client view of students but acknowledged that curricula often encourages students to self-identify as a passive customer rather than facilitating the process of becoming an effective lifelong learner. While not explicitly framed in SaP, Bunce, Baird, and Jones (2016) explored the consequences of students being considered customers in the UK, which drastically increased university fees in 2012. They administered a survey to 605 undergraduate students from 35 institutions in England and found that students with a "consumer orientation" tended to hold passive attitudes towards learning, which then had a negative impact on academic performance (Bunce et al., 2016). By working together as collaborative partners in the teaching and learning enterprise, SaP is a direct challenge to the idea that students or staff can be passive in the educational process.

Students in our study held generally high levels of perceptions of the importance of SaP activities, indicating a desire to be more actively engaged in partnership activities with staff. Afolabi and Stockwell (2012) suggested that university curricular tended to encourage passive learning. Results of our study also suggest curricular experiences are not providing the opportunities many students seek to be more actively involved in teaching and learning and in the enhancement of teaching and learning. There is a risk that universities seeking to embrace SaP as a central pillar of teaching and learning predicated on active involvement of students with staff are actually reinforcing passive modes of learning based on traditional student-teacher hierarchies in the formal curriculum. SaP practices in the formal curriculum need to be carefully considered, particularly in institutions embracing the SaP philosophy.

\section{Implications for SaP in assessment practices}

Assessment is central to teaching and learning. The development of assessment discourse (e.g., assessment driving learning, assessment for learning, and assessment as learning) signals the inextricable link between learning and assessment. Current concerns around effective feedback arising from both formative and summative assessment practices highlight the different understandings of what constitutes feedback between learners and teachers (Carless, 2006). A national Australian assessment reform project in higher education featured several principles of effective assessment practices, including that students and instructors should become partners in assessment predicated on the essential role of dialogue in assessment and feedback (Boud, 2010). In our study, students assigned high importance to selecting from a choice of assessment topics. Giving students choices in their assessment topics provides a degree of responsibility and ownership over their learning, which can encourage higher engagement with assessment pieces (Healey et al., 
2014; Waterfield \& West, 2006). Other ways to engage students as partners in the assessment process include a shared revision of student generated statements and questions (Fluckiger, Vigil, Pasco, \& Danielson, 2010). Benefits, such as increased student autonomy, are a good argument for increasing the prevalence of partnership practices in assessment (Healey et al., 2014). Student responses in our study indicate substantial scope for rethinking assessment practices in ways that give students more ownership, that offer more dialogic-based assessment and feedback tasks, and that create room to develop effective self-evaluative strategies.

\section{Implications for progressive development of SaP in the curriculum}

Our study did not find statistically significant differences between the perceptions of students by year level. This indicates that first-year students reported the same perception levels about the $18 \mathrm{SaP}$ activities as final-year students. Using a survey to explore a large sample of students, Mercer-Mapstone and Matthews (2015) investigated student perceptions of graduate learning outcomes and skills across a degree program that included students from varying year levels. Their curricular model, drawing on Knight's (2001) progressive development of curriculum, supposed that students reported their perceptions based on experience of the curriculum to date. Ideally, according to Mercer-Mapstone and Matthews, students would report high levels of perceptions of developing such outcomes and skills at each year level, suggesting that the skills or outcomes were embedded in all year levels sufficiently. In our study, students' perceptions of the inclusion of most of the SaP activities were low, including that SaP activities were not being progressively developed across the year levels of the curriculum.

As Matthews, Cook-Sather, and Healey (in press) recently argued, SaP challenges the traditional roles of being a student and being a teacher in ways that require those engaged to rethink their beliefs. They acknowledge that this re-imagining of roles is challenging as it shifts universities toward more egalitarian learning communities, which represents a significant cultural change. For such a cultural change to occur, activities based on SaP will need to suffuse the curriculum in ways that introduce new students to the practices and rationale for such approaches while building the depth of partnership activities as students progress through their degree programs. Thus, more systematic planning and development of curricula based on SaP ideas and practices are necessary. This also potentially mediates against student resistance to one-off SaP activities introduced into the degree program by enthusiastic instructors operating in fundamentally different ways from their colleagues.

\section{Implications for SaP research}

Our exploratory study conducted at a single university within one disciplinary context (biomedical sciences) sought to ask different questions about SaP compared to much of the current SaP research, which led to a research design drawing on quantitative methods that values students' perceptions. The results were revealing with some clear implications for SaP activities across the curriculum. This creates space for further SaP research that captures large numbers of students' perceptions about SaP that can guide further SaP practices focused at the whole of degree program level. Similar studies have been conducted with a focus on whole of degree program curriculum development of graduate learning outcomes by drawing on students' perceptions (Matthews, Adams, \& Goos, 2015; Varsavsky et al., 2014). The study also established an evidential baseline at a particular institution, which suggests that follow-up studies linked to efforts to further 
scaffold SaP activities across the degree program would be beneficial. Such studies could draw on this quantitative study while expanding into a mixed methods design that captured case studies, reflections, and narratives of students and lived experiences of staff engaging as partners.

Future research that allows for comparative studies in different disciplines and different institutional contexts would advance the field. The analysis by Bunce et al. (2016) revealed disciplinary differences in students' self-identification as passive or active learners, with Science, Technology, Engineering, and Mathematics (STEM) students being more likely to view themselves as passive learners. This suggests that disciplinary differences are a factor to consider in SaP practices and research, which makes sense given the depth of research into disciplinary differences that influence teaching and learning beliefs in higher education (Becher \& Trowler, 1989; Mårtensson, Roxå, \& Stensaker, 2014). As the field of $\mathrm{SaP}$ grows in both research and practice, the nuances of disciplinary differences will have to be explored.

Other avenues for further research are comparative studies of students and staff, similar to the Matthews and Mercer-Mapstone (2016) study exploring the perceptions of students and staff about curriculum development across a degree program, including both undergraduate and post-graduate degree programs. Ideally, as SaP becomes more common, perceptions of SaP across the curriculum will align around a shared responsibility for teaching and learning. Finally, exploring the perceptions of staff not involved in partnership practices would offer insight into potential barriers for implementing SaP practices more widely.

\section{CONCLUSION}

This study contributes to the growing body of research on SaP by asking questions of students about their perceptions of SaP across their whole degree program. The findings show that the students in our study want more involvement in SaP activities with implications for how SaP approaches are progressively embedded across university curricula and better linked with assessment practices. More large-scale research into SaP focused on curriculum development of whole degree programs would advance SaP practice and the SaP field of inquiry. Moving from small numbers of enthusiasts engaged in SaP to more collective curriculum efforts involving larger numbers of students and staff will not be easy. If we want the benefits of SaP to become more far reaching in our universities as part of broader cultural changes that upend notions of students as passive educational customers, then our efforts and research have to extend into curriculum development with SaP embedded across our degree programs.

\section{ACKNOWLEDGEMENTS}

We are grateful to the students who participated in our study, including Lorelei Hine for providing critical feedback on our manuscript. Parts of the results section of this article were drawn from Lauren Groenendijk's Honours thesis. 


\section{NOTE ON CONTRIBUTORS}

Kelly E Matthews is a Senior Lecturer of Higher Education at The University of Queensland in Brisbane, Australia, an Australian Learning \& Teaching Fellow, and an inaugural co-editor for the International Journal for Students as Partners.

Lauren Groenendijk completed her honours year at the University of Queensland in 2016 and is now in Medical School.

Prasad Chunduri is a Lecturer in the School of Biomedical Sciences at the University of Queensland.

\section{REFERENCES}

Afolabi, F., \& Stockwell, L. (2012, November 7). Graduate view: "We are not customers." The Guardian. Retrieved on 30 November 2016 from:

https://www.theguardian.com/higher-educationnetwork/blog/2012/nov/07/students-not-customers-graduate-view

Becher, T., \& Trowler, P.R. (1989). Academic tribes and territories. London: Society for Research into Higher Education and Open University Press.

Boud, D. (2010). Assessment 2020: Seven propositions for assessment reform in higher education. Australian Learning and Teaching Council. Retrieved from: http://www.olt.gov.au/system/files/resources/Assessment 2020 final.pdf

Bunce, L., Baird, A., \& Jones, S. (2016). The student-as-consumer approach in higher education and its effects on academic performance. Studies in Higher Education, 121. doi: 10.1080/03075079.2015.1127908

Butcher, J., \& Maunder, R. (2013). Going URB@N: Exploring the impact of undergraduate students as pedagogic researchers. Innovations in Education and Teaching International, 51(2), 142-152.

Carless, D. (2006). Differing perceptions in the feedback process. Studies in Higher Education, 31(2), 219-233.

Cook-Sather, A. (2002). Authorizing students' perspectives: Toward trust, dialogue, and change in education. Educational Researcher, 31(4), 3-14

Cook-Sather, A. (2006). The "constant changing of myself": Revising roles in undergraduate teacher preparation. The Teacher Educator, 41(3), 187-206.

Cook-Sather, A. (2014). Student-faculty partnership in explorations of pedagogical practice: A threshold concept in academic development. International Journal for Academic Development 19(3), 186-198.

Cook-Sather, A. (2016). Undergraduate students as partners in new faculty orientation and academic development. International Journal of Academic Development, 21(2), 151162.

Cook-Sather, A., Bovill, C., \& Felten, P. (2014). Engaging students as partners in teaching and learning: A guide for faculty. San Francisco: Jossey-Bass.

Dvorakova, L., \& Matthews, K.E. (2016). Graduate learning outcomes in science: Variation in perceptions of single- and dual-degree students. Assessment and Evaluation in Higher Education. 
Fluckiger, J., Vigil, Y., Pasco, R., \& Danielson, K. (2010). Formative feedback: Involving students as partners in assessment to enhance learning. College Teaching, 58(4), 136140.

Higher Education Academy (HEA) \& National Union of Students (NUS). (2011). Student Engagement Toolkit. Retrieved from: www.nusconnect.org.uk/campaigns/highereducation/studentengagement/tool kit/resources/

Healey, M., Flint, A., \& Harrington, K. (2014). Engagement through partnership: Students as partners in learning and teaching in higher education. Retrieved from the Higher Education Academy website: https://www.heacademy.ac.uk/engagement-throughpartnership-students-partners-learning-and-teaching-higher-education

Healey, M., Bovill, C., \& Jenkins, A. (2015). Students as partners in learning. In J. Lea (Ed), Enhancing learning and teaching in higher education: Engaging with the dimensions of practice (pp. 141-163). Maidenhead: McGraw Hill/Open University Press.

Knight, P.T. (2001). Complexity and curriculum: A process approach to curriculum-making. Teaching in Higher Education, 6(3), 369-381.

Lizzio, A., \& Wilson, K. (2009). Student participation in university governance: The role conceptions and sense of efficacy of student representatives on departmental committees. Studies in Higher Education, 34(1), 69-84.

Mårtensson, K., Roxå, T., \& Stensaker, B. (2014). From quality assurance to quality practices: An investigation of strong microcultures in teaching and learning. Studies in Higher Education, 39(4), 534-545.

Matthews, K.E. (2016). Students as partners as the future of student engagement. Student Engagement in Higher Education, 1(1), 1-5.

Matthews, K. E., Adams, P., \& Goos, M. (2015). The influence of undergraduate science curriculum reform on students' perceptions of their quantitative skills. International Journal of Science Education, 37(16), 2619-2636.

Matthews, K.E. Cook-Sather, A., \& Healey, M. (in press). Connecting learning, teaching, and research through student-staff partnerships: Toward universities as egalitarian learning communities. In V. Tong, A. Standen, \& M. Sotiriou (Eds.), Research equals teaching: Inspiring research-based education through student-staff partnerships. London: University College Press.

Matthews, K.E., \& Hodgson, Y. (2012). The Science Students Skills Inventory: Capturing graduate perceptions of their learning outcomes. International Journal of Innovation in Science and Mathematics Education, 20(1), 24-43.

Matthews, K. E., \& Mercer-Mapstone, L. D. (2016). Toward curriculum convergence for graduate learning outcomes: Academic intentions and student experiences. Studies in Higher Education, 1-16. http://dx.doi.org/10.1080/03075079.2016.1190704

Mercer-Mapstone, L., Dvorakova, S. L., Matthews, K. E., Abbot, S., Cheng, B., Felten, P., . . . Swaim, K. (in press). A systematic literature review of students as partners in higher education. International Journal for Students s Partners.

Nulty, D. (2008). The adequacy of response rates to online and paper surveys: What can be done? Assessment and Evaluation in Higher Education, 33(3), 301-314.

Seale, J., Gibson, S., Haynes, J., \& Potter, A. (2015). Power and resistance: Reflections on the rhetoric and reality of using participatory methods to promote student voice and engagement in higher education. Journal of Further and Higher Education, 39(4), 534552. 
Varsavsky, C., Matthews, K., \& Hodgson, Y. (2014). Perceptions of science graduating students on their learning gains. International Journal of Science Education, 36(6), 929-951.

Waterfield, J., \& West, B. (2006). Inclusive assessment in higher education: A resource for change (A Staff-Student Partnership for Assessment Change and Evaluation [SPACE] Project). Plymouth: University of Plymouth. Retrieved from:

https://www.plymouth.ac.uk/uploads/production/document/path/3/3026/Space tool kit.pdf

Weng, L. J. (2004). Impact of the number of response categories and anchor labels on coefficient alpha and test-retest reliability. Educational and Psychological Measurement, 64(6), 956-972.

Woolmer, C., Sneddon, P., Curry, G., Hill, B., Fehertavi, S., Longbone, C., \& Wallace, K. (2016). Student staff partnership to create an interdisciplinary science skills course in a research intensive university. International Journal for Academic Development, 21(1), 16-27. 